\title{
Canada's Patented Medicines (Notice of Compliance) Regulations: Removing Inefficiencies to Encourage Generic Competition
}

by

Suzanne Marie Porter

A thesis submitted in conformity with the requirements

for the degree of Master of Laws

Graduate Department of the Faculty of Law

University of Toronto

(C) Copyright Suzanne Marie Porter 2011 


\begin{abstract}
$\underline{\text { Abstract }}$
Canada's Patented Medicines (Notice of Compliance) Regulations: Removing Inefficiencies to Encourage Generic Competition, Suzanne Porter, LL.M 2011, University of Toronto Faculty of Law

Canada's Patented Medicines (Notice Of Compliance) Regulations fail to achieve the intended purpose of balancing innovation with timely generic market entry. An examination of the inefficiencies created by the Canadian regulations reveals that key features of U.S. pharmaceutical law should be adopted to improve the disjointed regulatory system that impedes generic competition. Specifically, the regulations should be amended to consolidate multiple proceedings into one cause of action that evaluates patent validity. An economic incentive to challenge weak patents should also be introduced in Canada. These features encourage competition without deterring pharmaceutical research and development because only patents that are not truly inventive will be invalidated after a full inquiry. As such, the intellectual property laws will continue to satisfy Canada's international intellectual property obligations and protect innovative medicines and allow recovery of costs and monopoly profits to new and useful pharmaceutical products.
\end{abstract}




\section{Table of Contents}

1. Introduction................................................................

2. The United States Hatch-Waxman Act......................................

3. Canada's Patented Medicines (Notice of Compliance) Regulations and Related Legislation.......................................................... 16

4. Patent Register Disputes................................................. 25

5. Litigation and Rights of Appeal......................................... 26

6. Automatic Stay and Entitlement to Damages.............................. 30

7. Extension of Data Exclusivity Protection.................................... 35

8. Evergreening under the NOC Regulations................................. 36

9. The High Cost of Canadian Generic Pharmaceuticals.......................... 38

10. The Comprehensive Economic Trade Agreement...........................42

11. Conclusion...................................................... 47 


\section{Introduction}

Pharmaceutical intellectual property protection has been the subject of much debate and litigation over the past several decades. The debate stems from the attempt to balance the potentially conflicting goals of pharmaceutical patent protection with timely market access for generics. Pharmaceutical patents, like all patents, are granted in exchange for full disclosure of new, useful, and non-obvious products or processes and provide a twenty year monopoly within which to recoup costs associated with research and development. ${ }^{1}$ Unlike other industries, however, pharmaceuticals are governed by a complex interaction of regulations that govern disclosure of information, patent validity and infringement, and generic market entry.

In the past, generic manufacturers seeking to sell their products in Canada were required to follow the same time consuming and expensive regulatory approval process as their brand competitors to gain market entry. Following ratification of the North American Free Trade Agreement (NAFTA) and the World Trade Organization's Agreement on Trade Related Aspects of Intellectual Property Rights (TRIPS), Canada changed these procedures and implemented regulations that allow generic manufacturers to rely on research and clinical studies conducted by brand manufacturers. ${ }^{2}$ The regulations seek to encourage generic competition by providing generic companies applying for market approval, also known as a "Notice of Compliance" (NOC), the opportunity to challenge brand patents to gain market entry

\footnotetext{
${ }^{1}$ Patent Act, RSC 1985, c P-4, s 44.

${ }^{2}$ North American Free Trade Agreement, U.S.-Can.-Mex., Dec. 17, 1992, T.S. No. 2 (1994), 32 I.L.M. 289 (between the Governments of Canada, Mexico, and the United States; entered into force Jan. 1, 1994) (hereinafter NAFTA); Trade Related Aspects of Intellectual Property (TRIPS) 1994, Oct. 30, 1947, T.S. No. 27 (1947), 58 U.N.T.S. 187 (negotiated as part of the Uruguay Round (19861994) of the World Trade Organization's General Agreement on Tariffs and Trade (GATT)
} 
before the expiry of the twenty-year patent term. These "linkage regulations," so called because of the link between market approval and patent validity, are unique to the pharmaceutical industry and existed in the United States for almost a decade before Canada was urged to follow suit.

There are two major differences between the U.S. and Canadian regulations. First, the U.S. regulations provide an explicit economic incentive for generic manufacturers to challenge brand pharmaceutical patents in order to gain market entry before the expiry of the patent term. Second, a generic challenge in the United States involves a full adjudication of the patents protecting the brand's product. If successful, the first generic challenger is rewarded with six months of market exclusivity designed to allow that challenger to recoup the often significant costs associated with the full discovery and litigation of the contested patents.

The original intent of the legislation "was explicitly to balance two competing policy objectives: inducing brand pharmaceutical firms to make the investments necessary to research and develop new drug products, while enabling competitors to bring cheaper, generic copies of those drugs to market as soon as possible." ${ }^{3}$ Yet, despite modeling the Canadian regulations after those in the United States, Canada's Patented Medicines (Notice of Compliance) Regulations (hereafter "NOC regulations") do not provide the same explicit link between patent validity and generic market approval. Rather, the NOC regulations require the generic

\footnotetext{
${ }^{3}$ R.A. Bouchard et al., "Structure-Function Analysis of Global Pharmaceutical Linkage Regulations" (2011) 12:2 Minnesota Journal of Law, Science \& Technology 391 at 407, online: http://works.bepress.com/cgi/viewcontent.cgi?article=1010\&context=ron_bouchard\&seiredir $=1 \#$ search $=\% 22$ intent $\% 20$ linkage $\% 2$ regulations $\% 22$
} 
manufacturer to make allegations of patent invalidity or non-infringement in order to gain marketing approval, but these issues are not ultimately decided upon in the proceedings. Instead, the allegations are submitted to the court to decide only whether the generic's arguments are "justified" and the NOC should issue. ${ }^{4}$ Without a full resolution of the allegations, the Canadian regime creates a number of problems including inequitable rights of appeal, multiple litigations over the same drug products, and opportunities for abusive strategies that improperly extend pharmaceutical monopolies. Furthermore, without a clear economic incentive to encourage private challenges under the NOC regulations, there are no means by which to correct these problems. ${ }^{5}$

In light of recent policy decisions by provincial governments to reduce generic reimbursement prices, "these policies may somewhat reduce the temporary windfall profits earned by the first generic, and may therefore reduce the financial incentive for generic firms to challenge patents on branded drugs." ${ }^{\circ}$ As of 2014, the Ontario government will reimburse generic drugs at $50 \%$ (rather than the recently reduced $25 \%$ rate) if generic entry resulted from litigation. ${ }^{7}$ While doubling the reimbursement amount is a step in the right direction, the premium will apply to all generic manufacturers, not just the first successful challenger. Therefore, it is

\footnotetext{
${ }^{4}$ Patented Medicines (Notice of Compliance) Regulations, SOR/93-133, s 6(2).

${ }^{5}$ P. Grootendorst, and A. Hollis, "Managing pharmaceutical expenditure" at 12 online: http://www.chsrf.ca/Libraries/Hospital_Funding docs/CHSRFGrootendorstPharmaExpenditures.sflb.ashx (hereinafter "Grootendorst and Hollis"). Grootendorst and Hollis note that the first generic product to enter the market will likely enjoy a temporary premium and may achieve a higher share of the market than subsequent generics. However, there is no set policy to ensure this result.

${ }^{6}$ Id.

${ }^{7}$ Id. at 16.
} 
unlikely that this will create the necessary motivation to challenge weak patents. To make a meaningful difference then, the NOC regulations should be amended to provide a U.S. Hatch-Waxman-type incentive for the first generic challenger. While the U.S. system is not without fault, it is clear that U.S. generic firms have the ability to recoup costs through the 180-day exclusivity period. Canadian generic manufacturers should be afforded the same reward.

Canada adopted its present regulatory scheme in response to pressure from the United States government during negotiation of the North American Free Trade Agreement (NAFTA). ${ }^{8}$ Prior to the enactment of the NOC regulations in 1993, Canadian generic products could enter the market upon payment of a compulsory license to the brand manufacturer. Some scholars argue that abandonment of the compulsory license scheme was unnecessary to comply with international intellectual property law standards and that the present system fails to encourage generic market entry. ${ }^{9}$ Considering the anti-competitive impact of the 1993 amendments to Canada's system, it is important to recognize that proposals set forth by the European Union during current trade negotiations threaten to once again disrupt Canada's pharmaceutical intellectual property legislation and further discourage generic market entry.

The proposals set forth by the EU purport to encourage innovation. However, careful consideration of the present system reveals that their effect would be to further

\footnotetext{
${ }^{8}$ R.A. Bouchard, "I'm Still You're Baby: Canada's Continuing Support of U.S. Linkage Regulations for Pharmaceuticals," (2010) 15:1 Marquette Intellectual Property Law Review 79.

9 S. Chatterjee, "Flexibilities under TRIPS [Compulsory Licensing]: The Pharmaceutical Industry in India and Canada," (2007) online: SSRN: http://ssrn.com/abstract=1025386
} 
extend exclusivity periods beyond what is required under international treaty obligations and discourage competition. As it stands, Canadian pharmaceutical patent protection is among the strongest in the world. ${ }^{10}$ This presents a challenge to generic manufacturers seeking to enter the market. To complicate the regulatory process, the NOC regulations create obstacles which are often abused by brand manufacturers to inhibit competition. As a result, costly legal battles are launched to resolve the issues. Under these conditions, it is not surprising that Canadian generic pharmaceutical prices are among the highest in the world. ${ }^{11}$ It can be argued that the anticompetitive effects of the EU proposals risk further increasing drug prices for both patented and generic pharmaceuticals. The resulting strain on consumers and provincial health plans due to increased costs will be especially detrimental due to the aging population.

This paper will argue that, based on the strength of Canadian pharmaceutical intellectual property protection, and the relatively small impact of the Canadian market on global innovation, Canada should avoid further extending monopoly rights for brand pharmaceuticals. Instead, Canadian legislators should clarify the current regulations to create a clear link between generic market approval and patent validity. This will eliminate some of the ambiguity of Canada's regime and reduce

\footnotetext{
${ }^{10}$ E. Iacobucci, "Innovation for a Better Tomorrow: A Critique," May 30, 2011, online: http://www.canadiangenerics.ca/en/news/docs/05.30.11\%20Innovation $\% 20$ for $\% 20 \mathrm{a} \% 20 \mathrm{Better} \% 20 \mathrm{To}$ morrow\%20-\%20A\%20Critique FINAL.pdf

${ }^{11}$ Canadian Institute for Health Information, "Drug Expenditures in Canada, 1985 - 2010" (April, 2011), online: http://secure.cihi.ca/cihiweb/products/drug expenditure 2010 en.pdf, see also Competition Bureau Canada, "Generic Drug Sector Study," (2007) at 3, online: http://www.competitionbureau.gc.ca/eic/site/cbbc.nsf/vwapj/Competition\%20Bureau\%20Generic\%20Drug\%20Sector\%20Study.pdf/\$FILE/Competit ion\%20Bureau\%20Generic\%20Drug\%20Sector\%20Study.pdf
} 
unnecessary dispute and litigation. Consolidating NOC proceedings with a full patent trial will provide brand pharmaceutical manufacturers with the right of appeal in NOC proceedings and ensure adequate protection of innovative drugs. This can be achieved by allowing full discovery and adjudication of any patents at issue in an NOC proceeding. Generic manufacturers will also benefit from a determination of patent validity during a NOC proceeding because they will avoid the uncertainty of another round of litigation after the NOC is issued by Health Canada and the product enters the market. Additionally, if a court decision renders a patent invalid or not infringed by a generic product, then other generic products are free to enter the market. This pro-competitive outcome will benefit Canadian consumers. Therefore, private challenges to weak pharmaceutical patents have "far reaching effects" and should be rewarded in Canada by economic incentives similar to those offered in the United States. $^{12}$

This paper will also examine the differences between the Canadian and U.S. statutory schemes for pharmaceutical patent protection and highlight the complications for both brand and generic manufacturers created by Canadian legislation. It will suggest that consolidation of multiple proceedings into one cause of action, and the addition of an economic incentive to challenge weak patents, will improve the disjointed regulatory system. These features of U.S. pharmaceutical law will serve to encourage competition without deterring pharmaceutical research and

\footnotetext{
${ }^{12}$ Rep. Henry Waxman, Statement to the Generic Pharmaceutical Association's First Annual Policy Conference: Securing the Future of Affordable Medicine (September 20, 2005), online:

http://www.waxman.house.gov/news_files/news_statements_generic_pharmaceutical\%20_association - 9.20.05.htm.
} 
development because only patents which are not truly inventive will be invalidated after a full inquiry. As such, the intellectual property laws will continue to protect innovative medicines and allow recovery of costs and monopoly profits to new and useful pharmaceutical products. These issues are explored in light of current international negotiations so that the potential effects of proposed amendments to Canada's regulatory framework can be fully appreciated.

The United States Hatch-Waxman Act

In 1984, the United States passed the Drug Price Competition and Patent Term Restoration Act, or "Hatch-Waxman Act," to balance protection for patented pharmaceuticals with improved market access for generics. ${ }^{13}$ Prior to 1984 , a generic manufacturer seeking market approval from the Food and Drug Administration was required to submit the same detailed information relating to the drug's safety and effectiveness as a new drug applicant. The legislative intent behind the HatchWaxman Act was to amend the Federal Food, Drug, and Cosmetics Act as well as the Patent Act to facilitate the timely market entry of generic pharmaceuticals. ${ }^{14}$ This is achieved by a streamlined application procedure that allows a generic manufacturer to file an Abbreviated New Drug Application (ANDA) to obtain FDA approval. ${ }^{15}$ Under this simplified procedure, the generic manufacturer need only prove that its

\footnotetext{
${ }^{13}$ The Hatch-Waxman Act was named after the Republican senator Orrin Hatch and the Democratic congressman Henry Waxman who sponsored the Bill.

${ }^{14}$ E. Lietzan, "A brief history of 180-day exclusivity under the Hatch-Waxman Amendments to the Federal Food, Drug, and Cosmetic Act," (2004) 59 Food Drug Law J. 287 at 320.

${ }^{15} 21$ U.S.C. $\$ 355(j)(1)(1994)$.
} 
drug is the "bioequivalent" of the approved brand product. ${ }^{16}$ If the drug is bioequivalent, the generic manufacturer may rely on the safety and effectiveness studies submitted by the brand manufacturer with the original New Drug Application (NDA). This saves a great deal of time, money and effort for the generic manufacturer because it eliminates the need to conduct clinical trials and prepare reports to submit with its abbreviated application. As a result, barriers to generic market entry are significantly reduced and competition is introduced to the pharmaceutical market.

In addition to demonstrating that the generic product is bioequivalent, HatchWaxman requires the generic manufacturer to address any patents listed in the "Orange Book" for the approved drug. The Orange Book is a registry of approved drug products maintained by the FDA. When a NDA is filed by the brand manufacturer, relevant patents are submitted as part of the application. Subject to certain time and subject matter restrictions, the patents are entered into the Orange Book along with the corresponding approved drug product. ${ }^{17}$ Upon filing its ANDA, the generic manufacturer must make one of four "certifications" with respect to each of the listed patents. Specifically, the generic must certify (i) that patent information

\footnotetext{
${ }^{16} 21$ U.S.C. $\$ 355(\mathrm{j})(1994)$. A drug is bioequivalent if the rate and absorption "is not significantly different from the rate and extent of absorption of the Orange Book-listed drug when administered in the same dosage." See Federal Trade Commission, "Generic Drug Entry Prior to Patent Expiration: an FTC Study," (2002) at 4, online: http://www.ftc.gov/os/2002/07/genericdrugstudy.pdf

${ }^{17}$ The Federal Food, Drug, and Cosmetics Act narrowly restricts patents that are eligible for listing in the Orange Book to those which claim a drug or its methods of use. However, brand manufacturers cleverly began to incorporate labeling instructions such as "take with food" into method patent claims that were used to prevent generic market entry. In Canada, as discussed infra, patents are currently are eligible for listing if they claim the medicinal ingredient, formulation, dosage form or therapeutic indication on the specific drug approved by Health Canada. Numerous disputes over patent listing eligibility have been heard by courts in both countries since the enactment of the linkage regulations.
} 
has not been filed, (ii) that the patent has expired, (iii) the date on which the patent will expire, or "(iv) that the patent is invalid or will not be infringed by the manufacture, use, or sale of the new drug for which the application is submitted." 18 When a certification is made under paragraph IV, the generic manufacturer must file an opinion with the patentee, or brand manufacturer, outlining the legal and factual basis for its assertion that the patent is invalid or not infringed. ${ }^{19}$

As a result of amendments to the U.S. Patent Act under Hatch-Waxman, the filing of the ANDA is deemed to be an act of patent infringement that provides the brand patentee with a cause of action against the generic applicant. ${ }^{20}$ Therefore, once the brand manufacturer receives the paragraph IV certification, it has forty-five (45) days within which to file the infringement action against the generic. When the brand files the action, FDA approval of the generic's ANDA is automatically stayed for the earlier of thirty (30) months, expiration of the relevant patents, or a judicial determination of invalidity or non-infringement. ${ }^{21}$

During the course of a Hatch-Waxman patent infringement action, the parties engage in full discovery and adjudication of the patent. This is important for several reasons. First, it creates a clear link between generic market approval and patent validity. Second, it provides the parties with the opportunity to engage in full discovery to challenge or defend the patent. Third, it provides a binding court decision that affords equal rights of appeal for both brand and generic parties. Fourth,

\footnotetext{
${ }^{18} 21$ U.S.C. $\S 355(\mathrm{~b})(2)(\mathrm{A})(1994)$.

${ }^{19}$ Id.

${ }^{20} 35$ U.S.C. $\$ 271(\mathrm{e})(2)(\mathrm{A})(2006)$. See Eli Lilly Co. v. Medtronic, Inc., 496 U.S. 661 at 678 (1990) (referring to the filing of an ANDA as a "highly artificial act of infringement.")

${ }^{21} 21$ U.S.C. $\$ 355(\mathrm{j})(5)(B)(\mathrm{iii})(1994)$.
} 
it avoids additional litigation to resolve patent disputes between the brand and first challenger. If the patent is invalidated during the course of the Hatch-Waxman proceeding, it will be invalid for all purposes. Therefore, all generic manufacturers benefit from the first challenger's efforts and, in turn, consumers benefit from the resulting competition.

All of these factors work together to create a balanced system that encourages and protects innovation while facilitating generic market entry. For example, brand innovation is protected to the extent that the patent enjoys a presumption of validity which must be overcome by "clear and convincing evidence" presented by the generic. $^{22}$ If the patent is not invalidated during the course of the action or the generic is unable to prove that it does not infringe, the FDA will not grant market approval to the generic and the brand continues to enjoy monopoly profits on the basis of its patent protection. On the other hand, if the generic manufacturer succeeds in the Hatch-Waxman proceeding, the FDA will grant approval to market the product.

As a reward to the first generic challenger, the Hatch-Waxman Act prohibits the FDA from approving another generic version of the same product until 180-days after marketing of the first ANDA product. ${ }^{23}$ As a result, the Hatch-Waxman exclusivity period provides an important economic incentive by allowing the successful challenger to market its product in the absence of any generic competition. In other words, the brand product is the only other approved version of the drug on

2235 U.S.C. $\$ 282$ (2006). See also Microsoft Corp. v. i4i L.P., No. 10-290, 564 U. S. at 2-3 (2011) (concluding that "[a] patent shall be presumed valid" and "[t]he burden of establishing invalidity of a patent or any claim thereof shall rest on the party asserting such invalidity.")

${ }^{23} 21$ U.S.C. $\$ 355(j)(5)(B)(i v)(1994)$. Certain provisions of the Act result in forfeiture of the 180-day exclusivity period including failure to market the product within 75 days of approval or by any agreement. 
the market during the exclusivity period. For this reason, the exclusivity period is often called a "mini-patent" because it provides a short-term limit on competition that allows a generic manufacturer to recoup the costs associated with challenging a brand patent. ${ }^{24}$ However, unlike the monopoly enjoyed under the brand's patent, the Hatch-Waxman exclusivity period expressly introduces a competing generic product to the market and merely prevents other generic drugs from entering the market during that period. As a result, consumers benefit in both the short and long terms. In the short term, even a single generic competitor will drive the price down. In the long term, the exclusivity period encourages other generics to eliminate monopolies created by a patent that was not truly inventive.

The impact of the 180-day exclusivity period can be measured in a number of ways. First, even though there is only one generic manufacturer introduced to the market, prices decrease significantly upon generic market entry. ${ }^{25}$ Second, lower prices provide better access and higher usage of pharmaceuticals that can provide a better quality of life for a larger portion of society. Third, the long-term increase the number of challenges to weak patents reduces the ability for brand companies to improperly extend monopolies over their most profitable drugs.

An increase in the number of patent challenges improves the likelihood that a drug will be available in generic form years earlier than it would be if consumers had

\footnotetext{
${ }^{24}$ While Hatch-Waxman expressly prohibits the FDA from granting market approval to any other challengers during the 180-day exclusivity period, it provides for immediate competition upon judicial determination of invalidity or non-infringement of any relevant patents. As a result, consumers benefit from the reduced drug price offered by the newly approved generic and need only wait six months before other generics enter the market. See 21 U.S.C. §355(j)(5)(B)(iv)(1994).

${ }^{25}$ Iacobucci, supra note 10 at 5.
} 
to wait for the expiry of multiple patent terms. ${ }^{26}$ The goal of the Hatch-Waxman Act is realized under these circumstances and, as articulated by Rep. Henry Waxman, "The consequences of leaving inappropriate patents in place are far-reaching: it threatens to significantly delay generic competition, forcing consumers, businesses, and governments to unnecessarily pay monopoly drug prices for much longer periods." 27

While the encouragement of patent challenges has far-reaching beneficial effects, none of these challenges is a threat to truly innovative pharmaceuticals. Rather, only weak patents that are ultimately proven invalid by overcoming a strong presumption of validity with "clear and convincing evidence" are eliminated as barriers to competition. $^{28}$

Some argue that, without the incentive provided by the 180-day exclusivity provision, few if any generic manufacturers would invest the time and money to risk challenging a brand patent because there would be no way to recoup the costs associated with that challenge. ${ }^{29}$ Perhaps not surprisingly, brand manufacturers use a number of strategies to effectively eliminate the incentive in order to reduce challenges to weak patents so as to enjoy longer periods of exclusivity within which to charge monopoly prices. While brand manufacturers are highly motivated to

\footnotetext{
${ }^{26}$ Grootendorst and Hollis, supra note 5 at 13.

${ }^{27}$ Rep. Henry Waxman, Statement to the Generic Pharmaceutical Association's First Annual Policy Conference: Securing the Future of Affordable Medicine (20 September 2005), online:

http://www.waxman.house.gov/news_files/news_statements_generic_pharmaceutical\%20_association 9.20.05.htm.

${ }_{28}^{28}$ Microsoft Corp. v. i4i L.P., No. 10-290, 564 U. S. ___ slip op. at 2-3 (2011).

${ }^{29}$ E. King, "Don't Bite the Hand That Provides Life-Saving Drugs: Application of the Hatch-Waxman and Sherman Acts to the Pharmaceutical Industry and the Detrimental Effects to Future Innovation in Order to Achieve Current Savings for Consumers,” (2004) 49 Vill. L. Rev. 591 at 602.
} 
defend their patents through litigation, it is much less costly and less risky to avoid that challenge altogether.

The most common way to disincentivize a generic challenge is to introduce an "authorized generic" to the market prior to or at the beginning of the exclusivity period awarded under Hatch-Waxman. An authorized generic is a version of an approved drug that is authorized by the brand manufacturer to enter the market in competition with the true generic. ${ }^{30}$ The brand may authorize a generic in one of two ways. It may (1) license a third party to market the brand's approved drug or the generic's own version of the approved drug; or (2) market a "pseudogeneric" through a subsidiary. ${ }^{31}$ Neither of these practices is expressly prohibited by Hatch-Waxman because the exclusivity provision applies only to the first generic ANDA filer who seeks to challenge the brand patents. ${ }^{32}$ The provision states that any application for market approval "shall be made effective on the date that is 180 days after the date of the first commercial marketing of the drug (including the commercial marketing of the listed drug)" by the first generic challenger. ${ }^{33}$

Not surprisingly, the U.S. Federal Trade Commission (FTC) takes a skeptical view of authorized generics. It echoes the assertions by many generic companies that

\footnotetext{
${ }^{30}$ E. Hore, "A Comparison of United States and Canadian Laws as They Affect Generic Pharmaceutical Market Entry," (2000) 55 Food and Drug L. J. 373 at 386.

${ }^{31}$ J. Thomas, "Authorized Generic Pharmaceuticals: Effects on Innovation," Congressional Research Service, January, 2010, online: http://www.cq.com/flatfiles/editorialFiles/healthBeat/reference/docs/022501.pdf

3221 U.S.C. $\$ 355(j)(5)(1994)$. See Mylan Pharmaceuticals, Inc. v. FDA, 454 F.3d 270 (4 ${ }^{\text {th }}$ Cir. 2006), (affirming that authorized generics are not prohibited by the 180-day exclusivity provision of HatchWaxman and may therefore be marketed in competition with the generic product that was the subject of the first ANDA.)

${ }^{33} 21$ U.S.C. $\$ 355(\mathrm{j})(5)(B)(i v)$ states that any application for market approval "shall be made effective on the date that is 180 days after the date of the first commercial marketing of the drug (including the commercial marketing of the listed drug)" by the first generic challenger.
} 
"in the long run consumers will be harmed because an expectation of competition from authorized generics will significantly decrease incentives of generic manufacturers to pursue entry prior to patent expiration." ${ }^{34}$ The FTC notes that settlement agreements are "[a]nother potential concern" because "the brand-name manufacturer will promise to forgo introducing an authorized generic in exchange for the first-filer agreeing to push back its entry date. ${ }^{35}$ As a result of concerns over the elimination of the 180-day exclusivity and other effects of authorized generics on competition, the FTC is examining "both the likely short-term competitive effects" and "the likely long-term impact" of the practice of authorized generics. ${ }^{36}$

The U.S. Congress has introduced legislation to abolish the practice of authorized generics. If passed, the Fair Prescription Drug Competition Act will amend the Federal Food, Drug, and Cosmetic Act to prohibit brand manufacturers from marketing a generic version of its approved drug from the time of receiving notice that an ANDA has been filed until the expiration or forfeiture of the exclusivity period granted to the generic manufacturer. ${ }^{37}$ This Bill illustrates the intent of the American government to preserve the regulatory incentive for private manufacturers to challenge brand patents and encourage generic market entry. It also demonstrates that the Hatch-Waxman exclusivity period is an essential component of the U.S. regulatory regime that serves to balance pharmaceutical intellectual property protection with generic market access.

\footnotetext{
${ }^{34}$ D. Wales, "FTC Initiatives to Promote Competition in the Pharmaceutical Industry," Remarks before American Conference Institute, June 6, 2007 at 19 online: http://www.ftc.gov/ftc/bcspeeches/walespharm.pdf last accessed May 6, 2011. 
Another approach aimed at removing the incentive of the 180-day exclusivity period is for brand manufacturers to convince consumers and physicians to switch to another patented version of the drug before the generic enters the market. ${ }^{38}$ Under this scheme, brand companies begin to promote "new improved" products using aggressive marketing campaigns to suggest that newer versions of their drugs are superior to those which have become or are about to become available in generic form. ${ }^{39}$ This has a direct, negative impact on the success of any generic product and is especially harmful to the first generic challenger's ability to recoup costs incurred in litigating the brand's patent on the original product. In the long run, the brand manufacturer's ability to discourage use of the generic product even before it enters the market dilutes or negates the intended effect of the 180-day exclusivity period and impedes generic market entry.

While ambiguities were discovered and abused in early versions of the HatchWaxman Act, "the FDA issued many guidance documents clarifying Hatch-Waxman with the goals of reducing generic approval time; improving ANDA application quality to avoid multiple review cycles; avoiding time-consuming legal delays; and closing 'loopholes' which delayed competition." 40

\footnotetext{
${ }^{38}$ J. Lexchin, "Canada's Patented Medicines Notice of Compliance regulations: balancing the scales or tipping them?" (2011) 11 BMC Health Services Research 64, online:

http://www.biomedcentral.com/1472-6963/11/64

${ }^{39}$ B. Mintzes, "Direct to Consumer advertising is medicalising normal human experience." (2002) 324 B.M.J. 908. One of the most common marketing strategies employed by brand manufacturers is to release an extended or controlled release form of an active ingredient that is about to be approved as a generic.

${ }^{40}$ M. Rumore, "The Hatch-Waxman Act - 25 Years Later: Keeping the Pharmaceutical Scale Balanced," (2009) online: www.pharmacytimes.com/publications/supplement/2009/GenericSupplement0809/GenericHatchWaxman-0809 (last accessed July 20, 2011)
} 
Overall, Hatch-Waxman legislation along with FDA guidance creates a clear link between generic market approval and patent validity. The proceedings engage the parties in a full inquiry into the merits of the listed patents and provide a final adjudication that applies equally to the immediate parties and to any potential generic manufacturer seeking to enter the market. It is because of these features that, by 2002, generics accounted for $47 \%$ of prescription drug volume, more than doubling the 1983 level of $19 \%{ }^{41}$ Furthermore, in 1983, only $36 \%$ of the top-selling brand name drugs had generic competitors in 1983, but by 1998 the competition level was almost $100 \%{ }^{42}$ Therefore, the Hatch-Waxman Act has achieved its stated goals.

Canada's Patented Medicines (Notice of Compliance) Regulations and Related Legislation

Canadian pharmaceutical regulations do not provide the same clear link between generic market approval and brand patent validity that is provided under U.S. law. Rather, generic challenges to brand patents in Canada are complicated by the interplay of three legislative and regulatory schemes which operate independently of one another. The first two, the Patent Act and the Food and Drug Act, reward and protect innovative drug development. Upon satisfying the conditions for patentability under the Patent Act, brand manufacturers have the right to exclude others from

\footnotetext{
${ }^{41}$ U.S. Congressional Budget Office, "How Increased Competition from Generic Drugs Has Affected Prices and Re-turns in the Pharmaceutical Industry" (July 1998) at 22, online: http://www.cbo.gov/doc.cfm?index $=655 \&$ type $=0 \&$ sequence $=1$

${ }^{42}$ Id. at 27.
} 
making, using, or selling its patented product for a period of twenty years. ${ }^{43}$ The purpose of this limited monopoly is to allow the innovator to charge monopoly prices for a limited period so that it may recoup costs associated with the development of innovative drugs. A pharmaceutical patent is granted in exchange for advancing medicine by disclosing new and useful medicines and methods of treatment that benefit society by improving quality of life and, in some cases, longevity. The brand patentee has a cause of action for any infringement of its statutory exclusivity privileges and enjoys a presumption of validity for all of its patents.

The Food and Drug Regulations contain data exclusivity provisions that add to the protection offered to brand companies under the Patent Act. Data exclusivity periods prevent disclosure of information submitted by brand companies for a minimum of eight years. ${ }^{44}$ As a result, data exclusivity prevents generic manufacturers from obtaining data upon which it can rely to file its ANDA. The impact of data exclusivity on generic market access will be discussed in more detail, infra.

The third regulatory scheme, entitled the Patented Medicines (Notice of Compliance) Regulations (NOC regulations), attempts to balance the protection afforded by the Patent Act and the Food and Drug Act by setting forth a simplified approval process for generic manufacturers that is linked to patents that cover the brand product. The NOC regulations are administered by the Office of Patented Medicines Liaison within the Therapeutic Products Directorate of Health Canada.

\footnotetext{
${ }^{43}$ Patent Act, RSC, 1985, c P-4, s 2.

${ }^{44}$ Food and Drug Regulations, CRC, c 870, s C.08.004.1
} 
The NOC regulations were enacted in 1993 and modeled after the U.S. HatchWaxman Act. They allow a generic manufacturer to file an abbreviated new drug submission (ANDS) that relies on the safety and effectiveness studies submitted by the brand manufacturer at the time of filing its NDS. ${ }^{45}$ Therefore, like HatchWaxman, the NOC regulations are linkage regulations that also require the generic manufacturer to address patents listed by brand manufacturers on the Register of Patents maintained by the Ministry of Health.

At the time of submitting an ANDS seeking permission for market approval, or "Notice of Compliance," the generic manufacturer must accept that it will not obtain approval prior to the expiration date of the patent. Alternatively, the generic may challenge the validity of the patent by filing a "Notice of Allegation," or NOA, that sets forth arguments that the patent is invalid or not infringed. The NOA is filed with the Minister of Health and the brand manufacturer. Like Hatch-Waxman, the brand must act within 45 days of receiving the notice. Unlike Hatch-Waxman however, the filing of an ANDS does not constitute an act of patent infringement. Rather, it provides the brand manufacturer with the opportunity to file a judicial review application seeking an order to prohibit the Minister from issuing the NOC. ${ }^{46}$ If a judicial review is filed by the brand, the Regulations trigger an automatic twentyfour month stay within which no NOC may issue. ${ }^{47}$ This automatic stay is the source

\footnotetext{
${ }^{45}$ The brand and generic manufacturers are referred to under the Regulations as the "first person" and the "second person" respectively. This terminology reflects the fact that the brand is the first to make a new drug submission and the generic is the second. See Patented Medicines (Notice of Compliance) Regulations, SOR/93-133, ss 4(1), 5(2)

${ }^{46}$ Patented Medicines (Notice of Compliance) Regulations, SOR/93-133, s 6(1). ${ }^{47}$ Id.
} 
of additional conflict between generic and brand pharmaceutical companies and will be discussed in more detail, infra.

Prior to the enactment of the NOC regulations, Canada's Patent Act permitted generic manufacturers to apply for a compulsory license to market a patented pharmaceutical product. A compulsory license "restricts the rights of a patent holder by authorizing third parties to make, use, and sell patented products without the consent of the patent holder." ${ }^{48}$ From 1923 to 1993, the Act allowed any person, usually a generic manufacturer, to apply for a license:

(a) where the invention is a process, to use the invention for the preparation or production of medicine, import any medicine in the preparation or production of which the invention has been used or sell any medicine in the preparation or production of which the invention has been used, or (b) where the invention is other than a process, to import, make, use or sell the invention for medicine or for the preparation or production of medicine. ... ${ }^{49}$

Under this provision of the Act, "the Commissioner of Patents was obliged to grant to the applicant a license to do the things specified in the application unless there existed a good reason not to grant such license." ${ }^{, 50}$

In exchange for the compulsory license, a generic manufacturer was required to pay a royalty to the brand manufacturer for the duration of any patents covering the drug. ${ }^{51}$ The royalty was originally paid directly from the generic to the brand.

${ }^{48}$ J. Feldman, "Compulsory Licenses: The Dangers Behind the Current Practice" (2009) 8 J. Int'1 Bus \& L 137.

${ }^{49}$ Patent Act, RSC, 1985, c P-4, s 39(4).

${ }^{50}$ Novopharm v. Eli Lilly, [1998] 2 S.C.R. 129 at para 3.

${ }^{51}$ M. Smith, "Patent Protection for Pharmaceutical Products in Canada - Chronology of Significant Events" Library of Parliament, (2000) online: http://dsp-psd.pwgsc.gc.ca/Collection-

R/LoPBdP/BP/prb9946-e.htm 
However, after recommendations by the Commission of Inquiry on the Pharmaceutical Industry in 1985 (the "Eastman Commission"), a special royalty fund was created. The royalty rate was "determined in accordance with a formula that took into account the value of a licensee's sales of compulsorily licensed products in Canada, the pharmaceutical industry's world-wide ratio of research and development to sales, plus 4\%." ${ }^{52}$ Distributions from the fund "to firms whose patents were under compulsory licence were to be based on the relative research intensity of the patentholding firms. ${ }^{, 53}$

Compulsory licensing of pharmaceuticals in Canada "became so routine that it led to the development of a domestic generic drug industry." ${ }^{, 54}$ Between 1969 and 1983, the period studied by the Eastman Commission, "almost $80 \%$ of the applications for licenses were granted, resulting in an average of approximately twenty compulsory licenses per year." ${ }^{, 55}$ However, the regime was abolished in response to intense pressure from the U.S. government and its strong pharmaceutical lobby during negotiation of the North American Free Trade Agreement. ${ }^{56}$ Upon signing NAFTA, Canada was persuaded that its obligations under the agreement required amendment of the Patent Act to specifically remove the compulsory license provision set out in section 39 .

The Supreme Court of Canada has "accepted the view" that Parliament removed the compulsory licensing provision and enacted the NOC regulations "with the intent

52 Id.

${ }^{53} \mathrm{Id}$.

${ }^{54}$ C. Chien, "Cheap Drugs at What Price to Innovation: Does the Compulsory Licensing of Pharmaceuticals Hurt Innovation?” (2003) 18 Berkeley Tech. L. J. 853 at 875.

${ }^{55} \mathrm{Id}$.

${ }^{56} \mathrm{Id}$. 
of thwarting the possible appropriation by generic drug companies ... of the research and development initiatives of innovators. ${ }^{, 57}$ Citing the Regulatory Impact Analysis that accompanied the NOC regulations, the Court noted that, "following the abolition of the compulsory licensing system, the government enacted the NOC regulations in order to protect the right of patentees by preventing generic manufacturers from marketing their products until the expiry of all relevant patents." ${ }^{58}$ Despite the suggestion that the regulations were enacted for the benefit of brand patentees, Justice Binnie, writing for the Court, concluded that "[i]t seems clear that the NOC regulations were introduced to help generic drug companies and at the same time to curb potential patent abuse by them." 59 The similarities in the wording of the NOC regulations to the U.S. Hatch-Waxman Act support the Court's conclusion, and illustrate that influence from the U.S. government had much to do with the abolishment of compulsory licensing and enactment of the NOC regulations. However, slight differences in the wording of certain provisions generate confusion, debate, and litigation in Canada.

\footnotetext{
${ }^{57}$ Bristol-Myers Squibb Co. v. Canada (Attorney General), 2005 S.C.C. 26 at para 45 (emphasis in original).

${ }^{58}$ Id. at para 46. (citing the Regulatory Impact Analysis Statement which states:

"As a general rule, judicial remedies are sufficient to address patent infringement. However, with the enactment of [the NOC Regulations] the government has created an exception to patent infringement allowing generic competitors to undertake any activities necessary to work up a submission to obtain regulatory approval of a product. This removes a patent right that may have otherwise been available to patentees to prevent generic competitors from obtaining such regulatory approval of their products.

These Regulations are needed to ensure this new exception to patent infringement is not abused by generic drug applicants seeking to sell their product in Canada during the term of their competitor's patent while nonetheless allowing generic competitors to undertake the regulatory approval work necessary to ensure they are in a position to market their products immediately after the expiry of any relevant patents." Regulatory Impact Analysis Statement, SOR/93-133, Canada Gazette Part II, Vol. 127, No. 6, at p. 1388.)

${ }^{59}$ Bristol-Myers Squibb Co. v. Canada (Attorney General), [2005] 1 S.C.R. 533, para 47; (2005), 253 D.L.R. (4th) 1; 39 C.P.R. (4th) 449.
} 
It has been argued that abolishing compulsory licensing in favour of the NOC regulations was unnecessary for two reasons. ${ }^{60}$ First and foremost, it was clearly unnecessary to facilitate market entry to a market that was already open to generic competition. Prior to enactment of the NOC regulations, generic manufacturers were free to enter the market upon payment of a royalty to the patent owner. As noted, the amount of the royalty increased according to the market value of the brand drug. ${ }^{61}$ Furthermore, one commentator notes that Canada's open market for generics under the compulsory licensing regime did not negatively impact innovation on a global scale because of the "relative insignificance" of the Canadian market. ${ }^{62}$

The compulsory license regime provided a certain balance between patent protection and generic competition without confusion and litigation. Therefore, Canada's decision to abolish the regime in favor of a system like the one in the U.S. does not achieve the goal of the legislation because it excludes two of the most important aspects of U.S. regulations: patent inquiry and a reward to the first challenger. These features should be added to the Canadian regulations to achieve the goals of encouraging generic market entry while preserving protection for innovative pharmaceuticals.

\footnotetext{
${ }^{60}$ Chatterjee, supra note 9.

${ }^{61}$ Smith, supra note 51.

${ }^{62}$ Chien, supra note 54 (noting that "[o]ver- reliance on compulsory licensing may also produce unintended negative downstream impacts on social measures other than innovation." The negative impacts include "discouraging domestic inventors, hindering foreign investment and technology transfer, and overshadowing regulatory or cooperative measures that might otherwise increase investment in local production facilities.") See also J.H. Reichman and C. Hasenzahl, "Non-Voluntary Licensing of Patented Inventions: Historical Perspective, Legal Framework Under TRIPS, and an Overview of the Practice in Canada and the United States of America," (2002) at 13, online: http://www.iprsonline.org/resources/docs/Reichman\%20-\%20Non-voluntary\%20Licensing\%20\%20Blue\%205.pdf (last accessed July 16, 2011).
} 
Second, introducing the NOC regulations as a way to ensure compliance with international obligations was unnecessary because Canada's compulsory license regime already satisfied TRIPS. One commentator points out that

To strike a balance between many countries' self-interested incentives to weaken domestic IP law and the globally desirable effects on innovation that result from ensuring some degree of IP protection, most countries around the world have entered into the TRIPS agreement which sets out a minimum standard of IP rights that signatory countries commit to adopting. Although large economies with strong pharmaceutical lobbies, such as the US and EU, sought more onerous minimum standards in TRIPS, other countries resisted ... It is worth noting that TRIPS contains many IP flexibilities especially geared toward promoting access to medicines when IP acts as an undue barrier. ${ }^{63}$

These flexibilities are set forth in article 30 which notes that

Members may provide limited exceptions to the exclusive rights conferred by a patent, provided that such exceptions do not unreasonably conflict with a normal exploitation of the patent and do not unreasonably prejudice the legitimate interests of the patent owner, taking account of the legitimate interests of third parties. ${ }^{64}$

While the term "compulsory license" is not used in the text of article 30 , article 31 specifically sets out certain conditions under which "use without authorization of the right holder" is permitted. ${ }^{65}$ Article 31 sets forth certain conditions listed in the article that must be satisfied. ${ }^{66}$ Specifically, Article 31 states that

b) such use may only be permitted if, prior to such use, the proposed user has made efforts to obtain authorization from the right holder on reasonable commercial terms and conditions and that such efforts have not been successful within a reasonable period of time. This requirement may be waived by a Member in the case of a national emergency or other

\footnotetext{
${ }^{63}$ Iacobucci, supra note 10 at 14.

${ }^{64}$ Agreement on Trade-Related Aspects of Intellectual Property Rights, April 15, 1994, Marakkesh Agreement Establishing the World Trade Organisation (WTO), Annex-IC, Legal Instruments results of the Uruguay Round, Vol. 1, 33 I.L.M, 181 (1994), Article 30, (hereinafter TRIPS)

${ }_{65}^{65} \mathrm{Id}$.

${ }^{66}$ TRIPS Article 31.
} 
circumstances of extreme urgency or in cases of public non-commercial use ...67

Therefore, Canada's compulsory license regime complied with the requirements of the TRIPS Agreement and Article 30 explicitly allows the use of patented medicines by a generic manufacturer as long as the generic attempted to obtain authorization directly from the brand patentee.

Given that Canada's pharmaceutical regulations fulfilled its international obligations before the NOC regulations were introduced, and allowed generic market entry with payment of a reasonable license to the brand patentee, it is clear that the motivation behind Canada's decision to abolish compulsory pharmaceutical licensing in favour of the present system had little to do with balancing innovation and generic market entry. Rather, it seems clear that the U.S.-based brand pharmaceutical manufacturers had much to gain by the amendments and sought to vigorously protect their monopolies on both sides of the border. In fact, the inefficiencies of the NOC regulations delay generic competition in Canada and force generic manufacturers to engage in lengthy court battles. The resulting costs are ultimately passed on to Canadian consumers.

\footnotetext{
${ }^{67}$ TRIPS Article 31.
} 


\section{$\underline{\text { Patent Register Disputes }}$}

Even before a generic manufacturer challenges the validity of a given patent, disputes arise over the eligibility of that patent to be listed on the Patent Register. ${ }^{68}$ Given the added protection afforded to the brand by listing multiple patents on the Register, the NOC regulations impose certain time and subject matter restrictions to determine which patents are eligible for listing. Patents are currently eligible if they claim the medicinal ingredient, formulation, dosage form or therapeutic indication on the specific drug approved by Health Canada. ${ }^{69}$ According to Section 4 of the NOC regulations, a patent list must be submitted to Health Canada by the brand manufacturer as part of its new drug submission and may only include patents that were filed prior to submission of the NDS. ${ }^{70}$ Patent applications pending at the time

\footnotetext{
${ }^{68}$ Importantly, only the generic manufacturer has the right to challenge listed patents. See Canadian Generic Pharmaceutical Association v Canada (Health), 2011 FC 465 (holding that the Canadian Generic Pharmaceutical Association does not have standing to challenge patent eligibility.)

${ }^{69}$ AstraZeneca Canada Inc. v. Canada (Minister of Health), (2003) 2 S.C.R. 560.

${ }^{70}$ Under Section 4 of the NOC Regulations:

4. (1) A first person who files or who has filed a new drug submission or a supplement to a new drug submission may submit to the Minister a patent list in relation to the submission or supplement for addition to the register.
}

(2) A patent on a patent list in relation to a new drug submission is eligible to be added to the register if the patent contains

(a) a claim for the medicinal ingredient ...

(b) a claim for the formulation that contains the medicinal ingredient ...;

(c) a claim for the dosage form ...; or

(d) a claim for the use of the medicinal ingredient ....

(5) Subject to subsection (6), a first person who submits a patent list must do so at the time the person files the new drug submission or the supplement to a new drug submission to which the patent list relates.

(6) A first person may, after the date of filing of a new drug submission or a supplement to a new drug submission, and within 30 days after the issuance of a patent that was issued on the basis of an application that has a filing date in Canada that precedes the date of filing of the submission or supplement, submit a patent list, including the information referred to in subsection (4), in relation to 
of submission may be added to the register within thirty days of issue. ${ }^{71}$ The patent must also include at least one claim for the medicinal ingredient, formulation, dosage form or use, or change in formulation, dosage form or use, for which an NOC is granted from the related substance. ${ }^{72}$ These timing and subject matter restrictions create additional sources of contention and litigation outside of the NOC proceedings and add to the overall inefficiency of the regulations.

\section{Litigation and Rights of Appeal}

The most notable difference between the U.S. Hatch-Waxman legislation and the Canadian NOC regulations is that the NOC regulations do not involve determination of patent validity or infringement. Instead, the action is limited to a judicial determination of whether the generic's allegation is justified. At the conclusion of the proceedings, if the allegation is not justified, the court will issue an order prohibiting the Minister from granting a NOC. The generic manufacturer has a right to appeal the court's decision as it continues to market its drug under the NOC regulations. Conversely, if the court determines that the allegation is justified, the Minister issues an NOC. In this case, the brand manufacturer has no right to appeal because the issues before the court relate only to whether the allegations are justified and whether the NOC should issue. Thus, an appeal becomes moot when the NOC is granted.

\footnotetext{
the submission or supplement. Patented Medicines (Notice of Compliance) Regulations, SOR/93-133, ss 4(1) - 4(6).

${ }_{71}^{71}$ Patented Medicines (Notice of Compliance) Regulations, SOR/93-133, s 4(4).

${ }^{72}$ G.D. Searle \& Co. v. Canada (Minister of Health) (F.C.), 2008 FC 437, [2009] 2 F.C.R. 293
} 
The summary nature of the NOC proceedings prohibits a full inquiry into the merits of the listed patent which, in turn, prevents equal rights of appeal for the parties. The Federal Court of Appeal confirmed that "patent validity, like patent infringement, cannot be litigated in this type of proceeding." ${ }^{, 73}$ However, the court explained that the drafters must have "had in mind the possibility of there being a parallel proceeding instituted by the [generic] which might give rise to such a declaration and be binding on the parties. ${ }^{, 74}$ This assumption illustrates that the NOC regulations go too far in attempting to simplify procedures because they omit the necessary link between patent validity and the issuance of a generic NOC.

Brand manufacturers argue that they should be afforded the right to appeal a judicial determination in a NOC proceeding and that NOC regulations are unfairly biased in favour of generic companies. However, even without the right of appeal, brand manufacturers have the opportunity to initiate patent infringement actions to block generic competition. Some brands are so eager to begin the second round of litigation that they attempt to bring infringement actions as soon as the NOC issues and before the generic product enters the market. The Federal Court of Appeal recently confirmed, however, that obtaining a NOC cannot support a quia timet action for future damages. ${ }^{75}$ The Court reasoned that it is unwilling to speculate that the generic will enter the market prior to patent expiry. ${ }^{76}$

Therefore, "generic drug companies are... forced to contend with a uniquely

\footnotetext{
${ }^{73}$ Merck Frosst v. Minister of Nat'l Health \& Welfare, (1994) 55 C.P.R. (3d) 302 at 319.

${ }^{74} \mathrm{Id}$.

75 Eli Lilly Canada Inc. v Nu-Pharm Inc., 2011 FC 255 at para 31 (citing AstraZeneca Canada Inc. $v$ Novopharm Ltd., 2009 FC 1209.)

${ }^{76} \mathrm{Id}$.
} 
burdensome system in Canada where marketing after a patent-contentious regulatory approval is always a risk." $" 77$ Furthermore, "[t]his risk is not trivial: brand damages from generic entry can far exceed generic revenues, due to the much higher profit margins earned by brands from monopoly pricing in the absence of generics.. ${ }^{, 78}$ As a result, the current NOC regulations create uncertainty for both generic and brand manufacturers that can only be settled through additional litigation. Yet, the risk is often greater for the generic company than for the brand because "even if a generic company has good reason to believe it will win in a subsequent infringement proceeding, the risk of potential damages in the event of a loss is unsettling", ${ }^{79}$

It is significant to note that "[i]t is possible for different results to be reached in parallel proceedings on the same drug and same patent. In a recent cast, the [generic], Apotex Inc., was prohibited from receiving a NOC for naproxen in various proceedings under the $\mathrm{PM}(\mathrm{NOC})$ Regulations, but commenced an action for a declaration that the patent in question was invalid, and was successful. The prohibition order granted years earlier was then set aside . . but only after the generic's NOC had been delayed for several years." ${ }^{\prime 80}$ While this is not always the result, it demonstrates the uncertainty created by the regulations and the necessity of additional litigation to gain market entry. In this case, the generic was forced to file a declaratory judgment action to avoid damages awarded in a patent infringement suit.

\footnotetext{
${ }^{77}$ Iacobucci, supra note 10 at 20.

${ }^{78} \mathrm{Id}$.

${ }^{79} \mathrm{Id}$.

${ }^{80}$ E. Hore, "A Comparison of United States and Canadian Laws as They Affect Generic Pharmaceutical Market Entry," (2000) 55 Food and Drug L. J. 373 at 386. (citing Hoffmann-LaRoche Ltd. v. Apotex Inc., File No. T-1898-93, April 30, 1999.)
} 
Consolidating the NOC proceedings with the determination of patent would avoid additional litigation and prevent this uncertainty.

At all stages, brand manufacturers are able to manipulate the system to prevent or delay competition. Therefore, it is important to "analyze the relative incentives of brands and generics to litigate questionable patents, which would be skewed further in favour of brand companies if an extra appeal were available." ${ }^{81}$ In fact,

Compared to sellers of other kinds of products, the NOC proceeding presents an additional hurdle to companies seeking to market a generic pharmaceutical product that could raise IP issues; other industries only have to litigate the validity and/or infringement of the relevant patent once, while generic manufacturers may have to litigate twice. The two litigation approach also prolongs the period of patent-related uncertainty compared to one patent action. ${ }^{82}$

To illustrate the enormous amount of time and money spent resolving issues under the

NOC regulations,

Apotex recently claimed that in the last 10 years, it has spent $\$ 800$ million on litigation. Extrapolating from this to the other generic and brand firms, it appears that annual litigation costs relating to pharmaceuticals in Canada are in the hundreds of millions of dollars, chiefly for litigation between generic and brand name firms. Indeed, there are in order of 100 Federal Court cases each year involving pharmaceutical patents. ${ }^{83}$

In fact, "Apotex has been a party in 432 different cases considered by the Federal Court and the Federal Court of Appeal since 1997." ${ }^{\text {" Th }}$ Thus, while they do not spend as much on research and development, generic manufacturers must face the risk and uncertainty of multiple rounds of litigation to compete with

\footnotetext{
${ }^{81}$ Iacobbuci, supra note 10 at 23.

${ }^{82}$ Id. at 19.

${ }^{83}$ Grootendorst and Hollis, supra note 5 at page 12.

${ }^{84} \mathrm{Id}$.
} 
brand products. Prior to 2006, generics faced even greater uncertainty because NOC procedures required generic challengers to address new patents added to the register after the NOA was filed and the NOC proceeding was underway. This delayed any resolution of the case. Recognizing the unfairness of this procedural tool, the NOC regulations were amended to prohibit brand companies from adding new patents to the register after the filing of the NOA. ${ }^{85}$

Therefore, neither the procedures themselves, nor the amount of time, money, and effort expended by the parties suggest that the NOC regulations are unfairly biased in favour of generics. To the contrary, the NOC regulations necessitate multiple actions and impede generic competition.

\section{Automatic Stay and Entitlement to Damages}

The automatic stay provided by the NOC regulations is another source of intense debate between Canadian generic and brand pharmaceutical companies. The dispute stems from the fact that the twenty-four month stay automatically issues when a brand files a Notice of Application to prohibit the NOC. ${ }^{86}$

The Supreme Court of Canada has repeatedly noted that "the automatic stay issued to patentees under the NOC regulations is an 'extraordinary' remedy, not available to patentees in any industry outside of the pharmaceutical industry." ${ }^{.7}$ The

\footnotetext{
${ }^{85}$ Government of Canada. Regulations amending the patented medicines (notice of compliance) regulations. Canada Gazette Part II 2006, 140 (21): 1503-1525.

${ }^{86}$ Patented Medicines (Notice of Compliance) Regulations, SOR/93-133, s 7(1).

${ }^{87}$ P. Grootendorst, and A. Hollis, "The Canada-European Union Comprehensive Economic \& Trade Agreement: An Economic Impact Assessment of Proposed Pharmaceutical Intellectual Property Provisions," Canadian Generic Pharmaceutical Association (February 7, 2011) at 3, (hereinafter "CETA Impact Assessment") online:
} 
Supreme Court has also emphasized that "under this procedure the court hearing the prohibition application has no discretion to lift the stay even if it thinks the innovator's case for interim relief is weak. Nor does the court have any discretion to leave the contending parties to their remedies under the Patent Act. The 'second person's' application for a NOC simply goes into deep-freeze until the statutory procedures have played themselves out. For these reasons, Iacobucci J. described the regime as 'draconian." " 88

At first glance, it is difficult to see why legislation that seeks to facilitate pharmaceutical competition provides a simple mechanism which allows a brand to block market entry by a generic competitor. It has been argued that the "mechanism decreases the likelihood of the detrimental situation that would occur if a generic manufacturer were to market its version of a pioneer drug prior to the resolution of the patent conflict and then subsequently lose the suit. Congress understood that such a situation would harm the public, destroy market share and pricing structure for the pioneer product, and expose the generic manufacturer to crippling damage claims" 89 Thus, the failure of the NOC proceedings to provide a full resolution of patent validity during the period of the stay negates any justification for the stay under the Canadian regulations. This inefficiency in the Canadian system creates an imbalance

http://www.canadiangenerics.ca/en/news/docs/02.07.11CETAEconomicImpactAssessmentFinalEnglish.pdf (last accessed August 18, 2011).

${ }^{88}$ Bristol-Myers Squibb Co. v. Canada (Attorney General), 2005 S.C.C. 26, 1 S.C.R. 553 (citing Merck Canada Inc. v. Canada (Minister of National Health and Welfare), (1998) 2 S.C.R. 193 at para 33, 80 C.P.R. (3d) 368.)

${ }_{89}$ Pharmaceutical Research and Manufacturers of America, "Delivering on the Promise of Pharmaceutical Innovation: The Need to Maintain Strong and Predictable Intellectual Property Rights," (2002) at 24, online: http://www.ftc.gov/os/comments/intelpropertycomments/phrma020422.pdf (citing Remarks of Rep. Waxman, House Floor Debate, Cong. Rec. of Sep. 6, 1984, at H9115.) 
in favour of brand manufacturers which can be corrected by incorporating patent validity litigation into the NOC proceedings.

Even though the automatic stay currently favours brand manufacturers by preventing generic market approval for up to two years, brand companies maintain that without the right of appeal, the NOC regulations create an injustice in favour of generics. This complaint is completely unwarranted in light of the fact that brand patents are not threatened by NOC proceedings. Even if the court decides that the generic's allegations of patent invalidity or non-infringement are justified, the patent remains valid and enforceable against the generic. Therefore, despite two years of legal wrangling and a successful court decision, the generic is in no better position than any potential patent infringer and the brand continues to enjoy its monopoly. The generic company must risk defending itself against allegations of patent infringement as soon as it enters the market. Any argument by brand manufacturers that the NOC regulations favour generics is, therefore, without merit.

Recognizing that generic manufacturers incur losses as a result of the brand's ability to prevent market entry during the period of the automatic stay, the NOC regulations attempt to provide a mechanism to impose liability on brand manufacturers for those losses. Section 8 of the NOC regulations sets forth the conditions under which the brand will be liable to the generic for losses suffered during the stay. Not surprisingly, further dispute and litigation between generic and brand manufacturers arise from disagreements about the interpretation and applicability of the section. Section 8 states:

8. (1) If an application made under subsection 6(1) is withdrawn or 
discontinued by the first person or is dismissed by the court hearing the application or if an order preventing the Minister from issuing a notice of compliance, made pursuant to that subsection, is reversed on appeal, the first person is liable to the second person for any loss suffered during the period

(a) beginning on the date, as certified by the Minister, on which a notice of compliance would have been issued in the absence of these Regulations ...

$\ldots$ and

(b) ending on the date of the withdrawal, the discontinuance, the dismissal or the reversal. ${ }^{90}$

The automatic stay in a NOC proceeding has the same effect as an interlocutory injunction without the requisite burden on the applicant to prove that there is a serious issue to be tried, that there is a likelihood of irreparable harm, and that a "balance of conveniences favours granting the injunction." 91 In other words, "[b]y merely commencing the proceeding, the applicant obtains what is tantamount to an interlocutory injunction without having satisfied any of the criteria a court would require before enjoining issuance of a NOC." ${ }^{, 92}$ The Federal Court of Appeal recently explained that "section 8 was not intended to provide redress where the innovator prevailed in the prohibition proceeding, even if the generic was later successful in patent litigation." ${ }^{93}$ Rather, "section 8 of the Regulations was intended to provide redress to the generic where the innovator failed to establish that the generic's allegations of invalidity or non-infringement were not justified. ${ }^{994}$

\footnotetext{
${ }^{90}$ Patented Medicines (Notice of Compliance) Regulations, SOR/93-133, s 8.

${ }^{91}$ RJR-MacDonald Inc. v. Canada (Attorney General), [1994] 1 S.C.R. 311, 337, 111 DLR (4th) 385, 54 CPR (3d) 114. See also N. Siebrasse, "Interlocutory Injunctions and Irreparable Harm in the Federal Courts," (2010) 88:3 Can. Bar. Rev. 515.

${ }^{92}$ Merck-Frosst Canada Inc. v. Canada (Minister of National Health and Welfare), [1997] 2 FC 561 (citing Bayer A.G. v. Canada (Minister of Nat'l Health \& Welfare), (1993) 51 CPR (3d) 329 at 337.) ${ }_{93}$ Apotex Inc. v. Syntex Pharmaceuticals International Ltd., 2010 FCA 155 at para 36. ${ }^{94}$ Id.
} 
Generally, the generic manufacturer is entitled to damages under section 8 if it succeeds in the NOC proceeding. However, the separation of NOC and parallel patent proceedings often frustrates the goal of compensating the generic manufacturer for being unjustly excluded from the market. For example, if the brand is successful in the NOC proceeding but the generic ultimately invalidates the patent on appeal, there is no way for the generic to recover losses resulting from being unjustly excluded from the market by that patent. Whereas, if the NOC regulations were not in place and the brand manufacturer obtained an interlocutory injunction, damages for the period of the injunction would be recoverable by the generic challenger. On the other hand, if the generic manufacturer is successful in the NOC proceeding but later found to infringe the brand patent, the brand "will nonetheless be liable to the generic under section 8 , even though it would not have been liable during the period of an interlocutory injunction."${ }^{.95}$

Entitlement to section 8 damages was recently considered by the Federal Court of Appeal. ${ }^{96}$ The court emphasized that "the recurring litigation surrounding the interpretation and application of section 8 show that there still seems to be some ambiguity concerning the interplay between NOC and impeachment proceedings." The court concluded that "it would be in the public interest and in the interest of would-be litigants" to provide "clear guidance" on the matter. ${ }^{98}$ To that end, the court affirmed that a generic manufacturer who is unsuccessful in the NOC proceedings but

\footnotetext{
${ }^{95}$ Id.

${ }_{97}^{96}$ Pfizer Canada Inc. v. Canada (Minister of Health), 2011 FCA 215.

${ }^{97}$ Id. at para 13.

${ }^{98} \mathrm{Id}$.
} 
ultimately proves the patent is invalid in the subsequent litigation generic can not "reach back and apply the finding of invalidity in the action" so as to argue that it is entitled to section 8 damages. ${ }^{99}$

\section{Extension of Data Exclusivity Protection}

Additional protection in the form of "data exclusivity" regulations, further benefit brand manufacturers and delay generic market entry. Data exclusivity prevents approval of a generic NOC for a minimum of eight years following brand approval. During the first six years, the generic company may not access the information submitted by the brand when it filed its New Drug Submission. Immediately following the six-year period is an additional two-year phase during which no generic submission can be approved. There is an additional six months of protection for pediatric drugs. ${ }^{100}$

The Canadian Generic Pharmaceutical Association (CGPA) unsuccessfully challenged the constitutionality of the data exclusivity regulations and argued that their enactment was an abuse of power. ${ }^{101}$ However, the Federal Court held that enactment of the regulations was "a valid exercise of the federal constitutional power under the regulation of trade and commerce, subsection 91(2) of the Constitution Act, 1867." 102 Regardless of the constitutionality of the data exclusivity regulations, some argue that granting a period of data protection for a patented product "fails to

\footnotetext{
${ }^{99}$ Id. at para 18 (citing Apotex Inc. v. Syntex Pharmaceuticals International Ltd., 2010 FCA 155 at para 36).

${ }^{100}$ Food and Drug Regulations, CRC, c 870, s C.08.004.1.

${ }^{101}$ Canadian Generic Pharmaceutical Association v. Canada, 2009 FC 725

${ }^{102}$ Id. at para 9.
} 
understand that patents are really an intellectual monopoly privilege granted in return for community access to data." ${ }^{\text {103 }}$ By preventing disclosure of information, these provisions of the Food and Drug Regulations not only delay generic challenges to brand patents but also conflict with the intent of the Patent Act itself.

Overall, the eight-year data exclusivity period exceeds the term required under Canada's international trade obligations and provides a significant advantage to brand pharmaceutical manufacturers because it delays any possible generic challenge and market entry.

Evergreening under the NOC Regulations

Another inefficiency created by the NOC regulations is the opportunity for pharmaceutical patent owners to improperly extend the monopolies on their best selling drugs beyond the limited period intended by intellectual property laws. This is a fundamental problem because "[t]here is a common misperception that generic competition arises following expiry of the patent. In reality, most branded products are protected by several patents that expire at different points of time." 104 Thus, brands are able to manipulate the life cycle of patents by filing them in such a way as to stagger their expiry dates. As new patents issue, they are entered on the patent

${ }^{103}$ T. Faunce, and J. Lexchin, "'Linkage' Pharmaceutical Evergreening in Canada and Australia" (2007) 4 Aust New Zealand Health Policy 8 online: http://www.ncbi.nlm.nih.gov/pmc/articles/PMC1894804 last accessed July 29, 2011.

${ }^{104}$ Grootendorst and Hollis, supra note 5 at 11. 
register and become a barrier that must be overcome by a generic manufacturer seeking market entry. This practice is commonly known as "evergreening."105

Another problem is that "[t]he NOC Regulations are intended to lead to a summary judicial review of the claims contained in the NOA. Instead of quickly resolving cases of patent infringement, however, the procedure has dramatically extended litigation in some cases." "106 For example, the commentators point out that litigation between the brand manufacturer AstraZeneca and the generic firm Apotex lasted 17 years and involved 12 different NOAs, 11 expert witnesses, 55 decisions from the Federal Court, 15 decisions from the Federal Court of Appeal, and 1 decision from the Supreme Court. ${ }^{107}$

Toward the end of 2006, the Canadian government sought to discourage abuses of the NOC procedures by limiting brand companies from extending their monopoly by adding new patents to the register that prevent or delay generic competition. ${ }^{108}$ The practice had the potential to extend the term of the brand's monopoly over a particular drug for an indefinite period. ${ }^{109}$ The amendments prohibit the addition of new patents to the registry after the generic manufacturer files the paragraph IV certification. This eliminates the brand's ability to generate multiple

\footnotetext{
${ }^{105}$ Bouchard, supra note 3 at $n 47$ ("Evergreening "is a potentially pejorative term that generally refers to the strategy of obtaining multiple patents that cover different aspects of the same product, typically by obtaining patents on improved versions of existing products." John R. Thomas, Cong. Research Serv., R40917, Patent "Evergreening": Issues in Innovation and Competition 1 (2009)). ${ }^{106}$ Id. at 12.

${ }^{107} \mathrm{Id}$.

${ }^{108}$ Government of Canada. Canada Gazette Part II Regulations amending the patented medicines (notice of compliance) regulations 2006, 140 (21): 1503-25.

${ }^{109}$ E. Hore, "Patently Absurd: Evergreening of pharmaceutical patent protection under the Patented Medicines (Notice of Compliance) Regulations of Canada's Patent Act," (2004), online: http://www.canadiangenerics.ca/en/news/docs/patently_absurd_04.pdf
} 
24-month stays by listing inappropriate patents. As such, generic companies are only required to address patents listed on the register on the date the NOC proceedings commence.

Even after the 2006 amendments, there is clear evidence that "the linkage regime can, in the hands of sophisticated firms, essentially double the cumulative term of patent protection on drug products." ${ }^{110}$ Brand manufacturers are able to yield "a term of extended patent protection, due solely to operation of linkage regulations, of about forty-three years per drug on average. The primary basis for this extension is the cumulative life of patents deemed legally relevant to the original product that were listed on the patent register to prevent generic entry."111 In other words, by carefully planning the filing dates of relevant patents, brand manufacturers are able to list relevant patents that will expire long after the original product patent expires. This abusive practice allows brand companies to extend their monopolies and create barriers to generic market entry long after the intended limited period.

\section{The High Cost of Canadian Generic Pharmaceuticals}

The costs associated with evergreening and increased litigation under the NOC regulations directly increase the cost to consumers as well as private and provincial health plans. Therefore, despite that the goal of the NOC Regulations is to facilitate market entry for lower priced generic pharmaceuticals, the effect has been to increase the price of Canadian generic pharmaceuticals to a point where they are among the

\footnotetext{
${ }^{110}$ Bouchard, supra note 7 at 96.

${ }^{111}$ Id.
} 
most expensive in the world. ${ }^{112}$ Some argue that prices remain high because of the inefficiencies created by the NOC Regulations. ${ }^{113}$

Overall, many inefficiencies in the NOC Regulations stem from the legislation's failure to provide a clear link between generic market approval and patent validity. To compound the problem, the absence of a full adjudication of listed patents creates a more complicated procedure for challenging brand products. The seemingly straightforward summary review afforded by a NOC proceeding is but the first step in a complicated series of disputes which impede generic market entry. The relationship between the NOC Regulations and the corresponding patent action in Canada is filled with uncertainty, risk, and expense for both brand and generic manufacturers. Ongoing disputes between brand and generic manufacturers relating to the interpretation and application of various provisions of the Regulations keep the courts very busy. For example,

Apotex has been a party in 432 different cases considered by the Federal Court and the Federal Court of Appeal since 1997. Apotex has also been a party to seven Supreme Court cases. Apotex recently claimed that in the last 10 years, it has spent $\$ 800$ million on litigation. Extrapolating from this to the other generic and brand firms, it appears that annual litigation costs relating to pharmaceuticals in Canada are in the hundreds of millions of dollars, chiefly for litigation between generic and brand name firms. Indeed, there are in the order of 100 Federal Court cases each year involving pharmaceutical patents. ${ }^{114}$

\footnotetext{
${ }^{112}$ Competition Bureau Canada, "Generic Drug Sector Study," (noting that Canadian prices for generic drugs are substantially higher than other countries) (2007) at 3, online:

http://www.competitionbureau.gc.ca/eic/site/cb-

bc.nsf/vwapj/Competition\%20Bureau\%20Generic\%20Drug\%20Sector\%20Study.pdf/\$FILE/Competit ion\%20Bureau\%20Generic\%20Drug\%20Sector\%20Study.pdf, see also Canadian Institute for Health Information, "Drug Expenditures in Canada, 1985 - 2010" (April, 2011).

113 Grootendorst and Hollis, supra note 5.

${ }^{114}$ Id. at 12.
} 
These statistics support the argument that brand manufacturers "now find it more lucrative to litigate than to innovate," because the brand continues to enjoy monopoly prices on its drugs for the duration of the proceedings. ${ }^{115}$ Considering the enormous profits enjoyed by brand pharmaceutical companies over a handful of blockbuster drugs, there is great incentive to zealously protect their intellectual property. ${ }^{116}$ In the end, however, it is the Canadian consumer who is harmed by paying higher prices to compensate for the endless litigation.

Brand companies argue that the NOC Regulations create an imbalance that favours generic manufacturers by allowing approvals based on bioequivalence to brand products, and inequitable rights of appeal. However, it is clear that brands enjoy a more certain position and lower risk during all phases of NOC proceedings and litigation. For example, during the initial NOC proceeding, the generic must argue that the brand patent is invalid without engaging in any discovery on the issues. During the patent infringement dispute, the generic again bears the evidentiary burden pharmaceutical patents, as all patents, are presumed valid. While Canadian courts have a low presumption of validity which need only be overcome by "evidence to the contrary," the generic must nevertheless provide some evidence to prove that its arguments are justified and the patent is invalid. ${ }^{117}$ To further complicate the

\footnotetext{
${ }^{115}$ E. Hore, "Patently Absurd: Evergreening of Pharmaceutical Patent Protection under the Patented Medicines (Notice of Compliance) Regulations of Canada's Patent Act," at 28, online: http://www.hazzardandhore.com/docs/papers/patently_absurd_04.pdf

${ }_{116}$ A "blockbuster" drug is "one which achieves annual revenues of over US\$ 1 billion at global level" in European Commission, Pharmaceutical Sector Inquiry, Preliminary Report (DG Competition Staff Working Paper), (November 28, 2008) at17, online: http://ec.europa.eu/competition/sectors/pharmaceuticals/inquiry/preliminary_report.pdf

${ }^{117}$ Patent Act, RS 1985, c P-4, s 45 states:
} 
procedure and impede generic market access, brands often list multiple patents to cover their drugs to ensure that if one barrier should be knocked down in the course of the proceedings, another will stand in its place to protect the brand's monopoly.

It is true that brand manufacturers often spend millions of dollars to develop many innovative medicines that benefit society. There is no dispute that research and development should be both encouraged and rewarded by offering intellectual property protection for innovative drugs. However, statistics show that less than $10 \%$ of profits go to R\&D. According to the latest report by Canada's Patented Medicines Price Review Board (PMPRB), only $6.9 \%$ of brand revenues (down from $7.5 \%$ in 2009) were spent on R\&D in Canada. ${ }^{118}$ Therefore, strengthening protection for brand pharmaceuticals does not necessarily translate into increased R\&D expenditures. The continual decline of these expenditures with the corresponding increase in litigation illustrates that a greater proportion of money is spent defending patents than researching novel medicines. Therefore, with the multitude of challenges facing generic pharmaceutical manufacturers to gain market entry, the NOC Regulations should provide an economic motive for the first generic challenger rather than increased protection for brand patentees.

Every patent granted under this Act shall be issued under the signature of the Commissioner and the seal of the Patent Office, shall bear on its face the date on which it is granted and issued and shall thereafter, in the absence of any evidence to the contrary, be valid and avail the grantee and his legal representatives for the term mentioned therein

${ }^{118}$ Patented Medicines Price Review Board, Annual Report 2010 (emphasizing that "with the adoption of the 1987 amendments to the Act, [brand manufacturers] made a public commitment to increase their annual R\&D expenditures to $10 \%$ of sales revenues by 1996." online:

http://www.pmprb-cepmb.gc.ca/english/view.asp?x=1441\&mid=1335 


\section{The Comprehensive Economic Trade Agreement}

Despite the inefficiencies created by the current NOC regulations that threaten generic competition and increase drug costs, Canada is currently considering proposals by the European Union to further increase protection for brand pharmaceuticals. ${ }^{119}$ The proposals are set forth in the intellectual property provisions in the Comprehensive Economic Trade Agreement (CETA) between Canada and the EU. Specifically, the CETA provisions that impact pharmaceutical intellectual property require Canada to provide, inter alia: (1) an additional 5 years of protection (or patent term extension) to compensate for administrative delays in marketing approval; (2) 10 years of data exclusivity; and (3) equal rights for brand and generic parties to appeal court decisions. ${ }^{120}$

To encourage support for the implementation of the EU proposals, brand pharmaceutical manufacturers sponsored a report published by the Canadian Intellectual Property Council of the Canadian Chamber of Commerce (CIPC Report). ${ }^{121}$ Not surprisingly, the CIPC Report recommends that Canada adopt the proposed changes to increase protection for brand pharmaceutical products. Specifically, the report calls for the Canadian government to grant brand manufacturers "an effective right to appeal an adverse court decision on a patent

\footnotetext{
${ }^{119}$ CETA Impact Assessment, supra note 87.

${ }^{120}$ Canada-EU Comprehensive and Trade Agreement, draft consolidated text (2011), online: http://www.nfu.ca/press releases/press/2010/Canada-EU\%20Draft.pdf (last accessed August 28, 2011)

${ }^{121}$ Canadian Intellectual Property Council and Canadian Chamber of Commerce, "Innovation for a Better Tomorrow: Closing Canada's Intellectual Property Gap," (2011) online: http://www.ipcouncil.ca/uploads/Innovation\%20for\%20a\%20Better\%20Tomorrow.pdf
} 
challenge." $" 122$ It also concludes that Canada "needs to implement" additional data protection and a five year patent term restoration system to account for regulatory approval delays for pharmaceuticals. ${ }^{123}$ These arguments are misleading and lack merit for a number of reasons.

First, both brand and generic manufacturers already have the right to appeal an adverse court decision on a patent challenge. As discussed, it is the judicial determination relating to the sufficiency of the generic's allegations that cannot be appealed by the brand because, once the NOC is granted, the issue becomes moot. Second, arguments suggesting that additional data protection and patent term restoration are necessary are equally meritless. According to Professor Edward Iacobucci, a noted scholar in the areas of business law and competition policy, "the arguments that the CIPC Report advances in favour of expanded IP rights are unpersuasive."124 For example, the CIPC Report argues that "other countries provide greater protection" than the eight years of data protection offered in Canada and that additional protection is necessary "[t]o remain competitive in the international marketplace." 125 However,

There are two seemingly crucial premises in their approach. First, greater IP protection in Canada will spur greater innovation to the benefit of Canadians, and will create jobs in the Canadian pharmaceutical sector. Second, the inappropriate weakness of Canadian IP becomes clear when one compares Canadian law with foreign law, particularly in the US and EU. Both premises are highly contestable. ${ }^{126}$

\footnotetext{
${ }^{122}$ CETA Impact Assessment, supra note 87 at 20.

${ }^{123} \mathrm{Id}$.

${ }^{124}$ Iacobucci, supra note 10 at 1.

${ }^{125}$ CIPC Report, supra note 121 at 16.

${ }^{126}$ Iacobucci, supra note 10 at 1 .
} 
Overall, the Report ignores the reality that the proposed pharmaceutical intellectual property provisions would create "the most extensive structural protection of innovative drugs of any country in the world."127

The CGPA also commissioned a report to analyze the economic impact of the pharmaceutical intellectual property provisions of CETA. The CGPA study concludes that the proposed language "would substantially increase the average time of exclusivity for patented drugs in Canada, and would give Canada the highest structural protection for patented drugs of any country in the world." ${ }^{28}$ It further concludes that the proposals "would increase the costs of purchasing drugs in Canada by billions of dollars annually."129 Therefore, the report proposes that "[i]f Canada wishes to increase its support for pharmaceutical innovation, there may be ways of achieving this goal that are more efficient, and less burdensome on government budgets, businesses and consumers than extending monopolies."

Yet another report, funded by the European Commission, indicates that the proposed changes to Canada's intellectual property regime under CETA will have a negative impact on Canada's economic growth. ${ }^{131}$ The report notes that stakeholders, including the Canadian Intellectual Property Council "assume a causal relation between weaker [intellectual property] protection and lower R\&D investments . . .

${ }^{127}$ CETA Impact Assessment, supra note 87 at 3.

${ }^{128}$ Id. at 44.

${ }^{129} \mathrm{Id}$.

${ }^{130}$ Id. (The report notes that alternative methods can be used to support the development of new drugs "such as directly sponsoring research through grants and tax incentives, or rewarding successful research on the basis of actual improvements in health ... or establishing national support for drugs for rare diseases.")

${ }^{131}$ EU-Canada SIA Final Report, "A Trade SIA Relating to the Negotiation of a Comprehensive Economic and Trade Agreement (CETA) Between the EU and Canda," (June 2011) at 322, online: http://www.eucanada-sia.org/ 
[and] consider that Canada's [intellectual property] regime 'undermines the country's innovation capacity and economic prosperity." ${ }^{\prime 132}$ To challenge this assumption, the report compares the experience of member countries of the Organisation for Economic Co-operation and Development (OECD) and concludes that

Some scientific studies contradict the industry's viewpoint and "fail to find evidence of a strong positive response by domestic innovators that could be reasonably ascribed to the effect of stronger IPR." To clarify, it is undisputable that R\&D spending is associated with higher GDP growth and, given current business models, a certain level of IPR protection is essential for investment in innovation and creativity. Incremental IPR reforms in OECD countries, however, do not seem to increase domestic spending in R\&D. ${ }^{133}$

The study highlights the fact that increased intellectual property protection will not necessarily result in increased $R \& D$ in Canada. In fact, given that Canada's current level of intellectual property protection for pharmaceuticals is among the strongest in the world, further strengthening the rights of patent holders risks creating "excessive" protection that would harm economic growth in Canada. Under these circumstances, the report cites the study commissioned by the Canadian Generic Pharmaceutical Association to point out that "every additional dollar invested in $R \& D$ as a result of CETA would cost an additional 8 dollars to Canadian consumers." ${ }^{, 134}$

Therefore, it is clear that the proposed amendments to Canada's pharmaceutical intellectual property protection set forth in CETA serve only to benefit large pharmaceutical companies. They will "very likely have a positive impact on the economy of the European Union, derived mostly from enhanced export

\footnotetext{
${ }^{132} \mathrm{Id}$.

${ }^{133}$ Id. (citing E. Lai, "International Intellectual Property Rights Protection and the Rate of Product Innovation," (1998) 55 Journal of Development Economics 133 at 153.)

${ }^{134}$ Id. (citing CETA Impact Assessment, supra note 87.)
} 
opportunities" for large pharmaceutical companies operating in the EU without providing any corresponding benefit to Canadians. ${ }^{135}$ As a result, Canada is facing pressures similar to those which influenced the enactment of the flawed NOC Regulations.

Considering the trivial impact of Canadian domestic law on global innovation and the strong protection currently available to Canadian pharmaceutical patentees, any suggestion that Canada must amend its intellectual property regulations to benefit brand manufacturers is baseless. ${ }^{136}$ In fact, "[t]he policy implication of the tenuous nexus between Canadian IP law and global innovation and research is that Canada should not strengthen Canadian IP law." 137 Canada must, therefore, be careful to avoid hasty amendments that may have negative implications for pharmaceutical competition and, ultimately, Canadian consumers. Given that the effect of the proposals will be to extend exclusivity periods beyond what is required under international treaties, and discourage competition, Canada must avoid signing CETA as presently drafted.

It is important to consider the domestic impact of international obligations in light of demographic changes. Specifically, Canada's aging population will strain the resources of provincial drug plans. As a result, lower drug prices and generic competition will become increasingly important. To provide additional protection to pharmaceutical intellectual property will only exacerbate the problems created by the NOC regulations. As the CPIC report points out, there will also be "a strong push"

\footnotetext{
${ }^{135}$ Id. at 294.

${ }^{136}$ Chatterjee, supra note 9.

${ }^{137}$ Iacobucci, supra note 10 at 13.
} 
for medical and pharmaceutical research. ${ }^{138}$ However, as discussed, only weak patents are invalidated by generic challenges and innovative patents remain in force so that research and development are not adversely affected.

Therefore, instead of adopting the EU proposals and imposing greater restrictions on generic market access, the NOC regulations should be amended to provide a direct link between generic market approval and brand patent validity. This will provide a full adjudication of patent validity and allow both parties to appeal the court's decision. As such, it will satisfy the EU's demand for equal rights of appeal for brand and generic manufacturers. With respect to the increased data exclusivity and patent term extensions, Canada is not obligated to provide protection which goes beyond its present international obligations, nor is it required to provide extensive protection that exceeds all other countries. Therefore, Canada should refuse to implement these additional protections that favour brand pharmaceutical manufacturers to the detriment of generic competition and, ultimately, Canadian consumers.

\section{Conclusion}

Despite the goal of the NOC Regulations to balance innovation with timely generic market entry, generic pharmaceutical manufacturers continue to face a number of challenges to market their products. In fact, the inefficiencies in the NOC regulations cause endless dispute and litigation that impede generic competition and make it more difficult to enter the market than in the past. Disagreements over listed

\footnotetext{
${ }^{138}$ CIPC Report, supra note 121 at 5.
} 
patents, automatic injunctions, rights of appeal, and confusing lost profit rules all contribute to delayed competition and increased prices for Canadian generic drug products. The regulations also create opportunities for brand manufacturers to manipulate the regulatory process to keep generics off the market for as long as possible. Perhaps the most inefficient aspect of the regulations is the requirement of a parallel action to determine issues of patent validity and infringement.

Thus, adopting key features of U.S. pharmaceutical law can solve many of the defects in the NOC regulations. Specifically, the regulations should be amended to consolidate multiple proceedings into one cause of action. This will improve the disjointed system and allow the court to make a binding decision on patent validity at the same time that it evaluates the generic manufacturer's allegations. This, in turn, will provide brand manufacturers with a right of appeal and eliminate any suggestion that the current regulations favour generics.

An economic incentive to challenge weak patents should also be introduced for the first generic challenger of brand pharmaceuticals in Canada. The long-term effect will be to encourage competition without deterring research and development, because only weak patents that are proven invalid will be removed as barriers to generic market entry. With these amendments, the intellectual property laws will continue to satisfy Canada's international intellectual property obligations and protect innovative medicines. Allowing recovery of costs and monopoly profits for innovative medicines, and increased competition will reward private efforts of both brand and generic manufacturers respectively. 
As Canada negotiates the Canada-European Union Comprehensive Economic and Trade Agreement, it must recognize that the proposed pharmaceutical intellectual property provisions would create extensive structural protection which exceeds that of any other country. Canada is not obligated to adopt additional safeguards that would further impede market access for generics and dramatically increase costs to Canadian consumers, businesses, and government insurers. Instead, the suggested amendments to the current regime will drastically improve the efficiency of the regulations and encourage generic competition. 